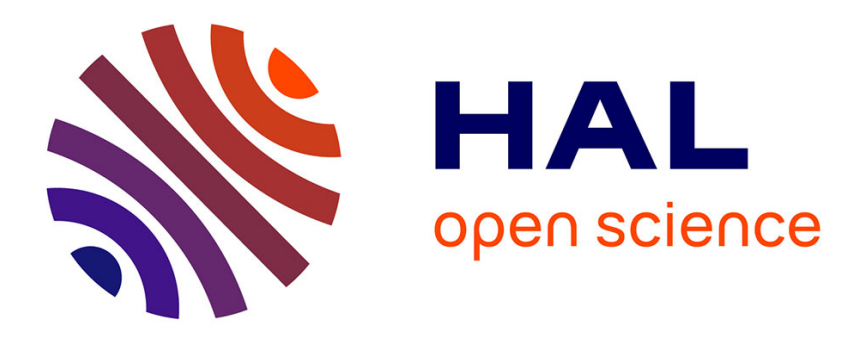

\title{
Improving SMEs' guidance within public innovation supports
}

\author{
Jean-Claude Boldrini, Emmanuel Chené, Nathalie Schieb-Bienfait
}

\section{To cite this version:}

Jean-Claude Boldrini, Emmanuel Chené, Nathalie Schieb-Bienfait. Improving SMEs' guidance within public innovation supports. 2009. hal-00423334

\section{HAL Id: hal-00423334 \\ https://hal.science/hal-00423334}

Preprint submitted on 9 Oct 2009

HAL is a multi-disciplinary open access archive for the deposit and dissemination of scientific research documents, whether they are published or not. The documents may come from teaching and research institutions in France or abroad, or from public or private research centers.
L'archive ouverte pluridisciplinaire HAL, est destinée au dépôt et à la diffusion de documents scientifiques de niveau recherche, publiés ou non, émanant des établissements d'enseignement et de recherche français ou étrangers, des laboratoires publics ou privés. 
EA 4272

\title{
Improving SMEs' guidance within public innovation supports
}

\author{
Jean-Claude BOLDRINI ( $\left.{ }^{*}\right)$ \\ Emmanuel CHENE $\left({ }^{*}\right)$ \\ Nathalie SCHIEB-BIENFAIT $\left(^{*}\right)$
}

$2009 / 29$

$\left({ }^{*}\right)$ LEMNA, Université de Nantes

INSTITUT

d'ECONOMIE

et de MANAGEMENT

de NANTES - IAE
Laboratoire d'Economie et de Management Nantes-Atlantique Université de Nantes

Chemin de la Censive du Tertre - BP 52231 44322 Nantes cedex 3 - France

www.univ-nantes.fr/iemn-iae/recherche

Tél. +33 (0)2 40141719 - Fax +33 (0)2 40141749 


\title{
Improving SMEs' guidance within public innovation supports
}

\author{
Jean Claude Boldrini, Emmanuel Chené, Nathalie Schieb-Bienfait \\ LEMNA - Université de Nantes
}

\begin{abstract}
In the eighties, public bodies became aware of the importance of the SMEs in the regional economic development. In order to stimulate their innovativeness and to overcome their inward limits, public policies set up innovation agencies all over European countries. Criticisms arose after ten years of existence because of their low usefulness. This article aims to develop a better understanding of the relationship between SMEs and innovation agencies (RTTAs - Regional Technology Transfer Agencies) : it presents the implementation of a management scheme which experimented new solutions, in French SMEs, to overcome previous gaps. Our article seeks to enrich researches exploring the links between the SME and the RTTA ; it advocates new principles to improve SMEs' guidance in innovation processes.
\end{abstract}

Keywords: innovation support instruments, innovation agencies, public support schemes, guidance, SMEs.

\section{Introduction}

For the past twenty years, public policies have devoted an increasing attention to the innovation capabilities of Small and Medium-Sized Enterprises (SMEs). These firms have been encouraged to adopt innovation-oriented strategies through regional, national or supranational incentives for two reasons. Firstly, they play an important economic role as they contribute to develop employment and to maintain economic competitivity. Secondly, their strengths lie in specific resources and abilities such as creativity, flexibility and closeness to their customers. Both innovation and processes are nevertheless different in SMEs and in large companies. If the competitiveness of SMEs stems more from incremental innovations rather than formal research or R\&D function, their innovation processes are confronted with a lack of resources. To overcome these limits, many European regions have set up, in the mid-80s, regional technology transfer agencies (RTTAs) in order to support the endogenous potential of innovation (Hassink, 1996, 1997 ; Vickers \& North, 2000 ; North and al., 2001). 
One decade later, the research of the previously mentioned authors have scrutinised the role and missions of RTTAs putting into question their usefulness : at the European level, they have drawn attention to the innovation deficiency and the incapacity of firms to develop new products and services (Hassink, 1996). According to Hassink (1996), North and al. (2001) and Kaufmann and Tödling (2002), three kinds of reasons can explain this situation. First, SMEs experience difficulties in accessing financial, technological, human and information resources. Second, the support schemes are regularly accused of mistargeting the SMEs needs and not identifying efficiently their deficiencies. Third, the RTTAs' impact on regional economic development is rather low because very few technology-following SMEs use them as an external resource Facing this situation our research question deals with the ways of improving the public innovation supports dedicated to SMEs, through new management schemes providing them with innovation impetus. The foundational frameworks presented here were chosen for their particular relevance in analyzing innovation process management in a multi-level and pluralistic context ${ }^{1}$ (Denis and al., 2007).

We begin this article by briefly reviewing the previous literature dealing with the innovativeness characteristics of SMEs, the functions of RTTAs and the discrepancies between SMEs demand and RTTAs supply. These approaches provide useful theoretical concepts for understanding the management of innovation processes. Second, we describe the experiment based on an innovation support scheme which was introduced to help SMEs in solving technical problems. Third, after a description of the research methodology, we present the results in terms of actors' assignment and coordination in the context of regional economic development and innovation policies (Cooke \& Morgan, 1993, 1998; Lundvall-Borrás, 1997). Finally we discuss the 
implications and suggest directions for the improvement of practices which should allow RTTAs to better meet SMEs needs and to develop more appropriately their innovation capabilities.

\section{Supporting innovativeness in SMEs}

Until the 1970s, innovation was considered as the affair of large companies able to convert scientific research to industrial products via large technological projects. In the 1980s governments realised that innovation policies ignored the SMEs. Moreover, they became aware of the necessity to promote the regional potential in order to encourage internal answers to tackle problems such as declining industry or economic improvement in weak areas. In the context of the European integration process, regional decentralised innovation policies grew in importance. They covered all the measures able to stimulate the firms innovativeness. The central aim was to support regional potential by encouraging the diffusion of new technologies from higher education institutes (HEI), public research establishments (PREs) and large firms to SMEs. It was assumed that raising SMEs competitiveness would save jobs, or even better, create new ones. Three types of measures were introduced: 1) financial aids to support technological innovativeness, 2) intermediary structures to act as a bridge between HEIs, PREs and SMEs and to transfer technology and 3) implementation of new infrastructures such as science parks, technopoles or incubators (Hassink, 1996, 1997). Despite the particular attention devoted to SMEs, RTTAs experienced difficulties in targeting them and in identifying adequately their support needs (North and al., 2001). 


\subsection{SMEs and innovation}

Some researchers have explored how the characteristics of SMEs influence their innovativeness or explain the salient difficulties of RTTAs (North and al., 2001 ; Hausman, 2005). In this article, we have chosen to develop the importance of dealing with the manager's personality according special attention to the way resources are managed, as well as the frequent technological orientation of SMEs and their practices in information search.

Vickers \& North (2000) observed that the personality of the managing director or the founder is considered as a key determinant for the innovative success of the firm. According to Raymond and al. (2004), understanding the SMEs requires firstly to focus on the analysis of its manager's or owner's profile and motivations. As he has the power, as he creates the strategy and as he is often reluctant to delegate authority, the innovativeness of the firm depends mostly on him. Owners tend to reject external help for reasons such as doubts about value for money, scepticism about generalist advice or preference for autonomy (North and al., 2001). This is why they prefer informal rather than formal channels of support.

SMEs face limited internal resources especially regarding finance, time and employees' know-how. Limited human resources can hinder a firm's propensity and ability to be aware of, and respond to, opportunities and threats in the environment. Limited managerial resources, immediate time pressures and lack of in-house expertise are barriers in accessing external resources. These problems hamper small firms in transforming their superior customer knowledge into new products and services (Hausman, 2005). 
In these firms, Vickers and North (2000) as well North and al. (2001) observed an overemphasis on technical development and, reciprocally, a lack of marketing involvement and of managerial skills. SMEs do not use any formalised methods to assess ideas and to manage projects. This can lead to serious decision mistakes and financial difficulties (Raymond and al., 2004).

Their information search is based on existing, informal and highly personalised networks because of a strong need for trust which is a precondition to exchange valuable knowledge. As a consequence, SMEs have few external relations in the innovation process, except with business partners and especially customers. Kaufmann and Tödling (2002) noted that the lack of interaction with external knowledge providers seriously restricts the influences enabling or stimulating innovation.

According to North and al. (2001), these internal limits were key justifications, in the mid-80, for RTTAs to provide support to SMEs.

\subsection{Regional Technological Tranfer Agencies : roles and assignments}

RTTAs can be organisations either independent or linked to HEIs or PREs. Most of them are publicly funded. They can act : 1) as brokers in general consultancy agencies, 2) in helping firms to solve technical problems by transferring technology and 3) in carrying out joint R\&D projects. RTTA consultants visit SMEs randomly and try to solve their problems (technological locking, lack of expertise, etc.). By helping managers to analyse their own company and to formulate their needs, they can refer to other RTTA experts. They stimulate networking and cooperation among SMEs within regional context. Advice on technological issues and aid schemes is provided through information, training sessions for SME employees and new technologies demonstrations. RTTA consultants may also tutor SMEs in order to raise aspirations 
and support the latent innovative potential of the most promising clients. Initial advice is often free of charge at least up to a certain number of days (Hassink, 1996, 1997 ; Vickers \& North, 2000).

Despite a large variety of activities, the last studies conducted on RTTAs after ten years of existence are often mitigated and have led to doubts about their usefulness for regional economic development (Hassink, 1996).

\subsection{Discrepancies between SMEs demand and RTTAs supply}

The main criticisms addressed to the RTTAs, as intermediary organisations, point out the excessive number of structures, their mistargeted innovation support and management, their owner centred approach and their technological orientation.

The proliferation of support agencies has introduced some confusion : RTTAs are not well linked and they have neither a good knowledge of each other's capabilities nor the motivation and commitment to signpost effectively (Vickers \& North, 2000). Arrangements are often so complex that they are confusing, even for those who are highly involved in them. So firms complain about the lack of transparency with regard to the RTTAs' roles and assignments (Kaufmann \& Tödling, 2002). In their defense, the SME population is also heterogeneous and it is difficult to design innovation supports which can match the specific problems and needs of a large variety of firms. Three kinds of misalignments can be observed in the management practices to support innovation. First, Hassink (1996) drew attention to the mismatch between the aid offered and the companies needs. The support instruments do not target the utmost problems constraining the innovation activities in SMEs. RTTAs are often source-(or supply-)oriented which prevents SMEs from defining their problems and in formulating

their demand. Second, there is a mismatch between the targeted firms and those which 
really need support: high-tech innovation projects and already innovative firms are often preferred to less technologically advanced or innovative firms (North and al., 2001 ; Kaufmann \& Tödling, 2002). Technology-following SMEs and structurally weak and inward-looking firms should be a target group of transfer agencies. Paradoxically, they tend to be ignored despite the fact they do not even have the capabilities to apply for support (Hassink, 1996 ; Kaufmann \& Tödling, 2002). Third, consultants, due to their academic background, speak to the manager from a managerial perspective rather than in an entrepreneurial spirit. This hinders them from having a positive perception of the SME characteristics (Raymond and al., 2004).

The consultants in innovation agencies have an owner centred approach. They make the first contact with the manager/owner due to his dominating position in the firm. This leads to limit their action in two ways. First, the owner is often reluctant to formalise his idea and to associate his staff in the project. Second, problems may occur in the progress of the project as the manager is monopolised elsewhere without having delegated someone to act in his place (Chanal, 2001).

In order to overcome both strategic deficiencies and organisational weaknesses, this article explores the ways of developing new interactions for new value creation sources, through a new experimentation based on the $\mathrm{TRIZ}^{2}$ method. The research question is focused on the innovation management process in a pluralistic context including the firm, the RTTA, the TRIZ method expert and public bodies.

\section{The SMEs innovation support scheme}

The scheme "Methodological Support for the Research of Innovative Technological Solutions in SME projects" was lead by two innovation agencies - Pays de la Loire Innovation (PLI) and $\mathrm{ADEPA}^{3}$ - working with a dozen of companies of the Region 
Pays de la Loire (west of France). Their public mission was to support regional companies in their technological evolution and innovation. Two novelties, with regard to their previous practices, were experienced : 1) the use of the TRIZ method for the research of innovative technological solutions in response to industrial problems and 2) a twofold assistance of the SMEs (TRIZ expert and " project bearer").

The industrial projects ( 5 examples in table1) were selected by a steering committee. The choice fell on manufacturing companies from twenty to two hundred employees which were developing their own products. The majority of the projects also involved training institutions (TI) in which students carried out industrial projects for local companies.

Table 1. Five companies and their industrial projects.

\subsection{The actors}

The support instrument includes various actors (figure 1). The company is generally represented by a member of the design office or by a production manager. Although the company is the main scheme beneficiary, its members do not participate directly when they have entrusted a study to a training institution. Two ADEPA's engineers, who were TRIZ method experts, shared the management of the projects. The relationship between the company and the scheme initiators is provided by the project bearer. He can be a PLI's technological counselor or a teacher. According to each individual case, students are either associated with the scheme or not. Project bearers and TRIZ experts are the" change agents" (Rogers, 1995) as they strive for improvement in the practices of SMEs. A PLI's technological counselor acts as a project manager. PLI and ADEPA members form the instrument hardcore as initiators, instigators and providers of the 
resources necessary for carrying out the industrial projects. Members of the two agencies sit on the steering committee with public bodies representants (Region and Ministry of Industry) to regulate its functioning. The instrument organisers can call on a Regional Technological Development Network which groups together the competencies of more than one hundred innovation actors.

Figure 1. The actors of the support instrument.

Companies owners have various expectations concerning the support instrument. Some have an industrial problem to solve. Others are looking for innovative solutions for a future product. A third category wishes to introduce a design method which could help the company in organising its development activities. Some companies report at least an " interest for the TRIZ approach"4 independently of any result. Companies have entrusted their project to a training institution because they had " no time to develop it internally " or because it did not fit with their trade.

The SMEs designers generally do not know TRIZ at the beginning of the scheme and are not especially seekers of the help offered through the support instrument. Some welcome the opportunity that has arisen while others consider having been involved " in a quasi compulsory way"

\subsection{The approach to handling the industrial cases}

The handling of the industrial projects is based on the three steps of the TRIZ method (figure 2).

Figure 2. Approach to solve a problem with TRIZ. 
First, it is important to take a step back from the initial setting of the problem, described in a topic documentation. The TRIZ method requires the modelisation of the problem with the statement of technical or physical contradictions. The aim of formulating contradictions is to avoid the direct way from the problem to the solution and the compromises between antagonistic parameters. These two practices are forbidden in TRIZ because they lead to solutions considered as mediocre and uncreative. The statement of a contradiction must allow, on the contrary, to confront this contradiction and to overcome it in the search for solutions. In the second step, tools for problem solving are put into use to obtain models of solutions. These are generic solutions coming from a database created from millions of patents. The models of solutions are interpreted, in the third step, to result in solution concepts. The TRIZ method stricto sensu stops at this point. Its results are only concepts whose feasibility is to be established (Altshuller, 1999).

Technology-independent, the TRIZ method opens the field of solutions significantly thanks to its powerful ability to set questions. TRIZ is for many the only creativity method joining new ideas and concepts of solutions. For this reason, it is sometimes considered as the missing link among the design process tools. The new solutions which stem from it may be shaped in new products capable of strengthening the competitive advantage of SMEs.

Four half day meetings are dedicated to the collective work between the TRIZ expert, the project bearer and the company or its representant (TI) (figure 3). Generally the expert works out the models of solutions alone between two meetings.

Figure 3. Typical development of a project. 
The first two meetings come within the TRIZ approach. The necessity of a scoring meeting appears when the scheme organisers become aware that SMEs are unable to value a list of solutions without the criteria to differentiate them. A follow-up meeting is set up to encourage the companies to go further with innovative solutions and to validate them in terms of feasibility. For lack of these meetings, innovative ideas are forgotten once the support agencies leave. Apart from the meetings, the project bearer is the conductor of the informal trade actors.

\section{Methodology and analysis}

\subsection{Data construction and analysis}

At the support scheme launch, the PLI's director submitted a research question to us. It concerned the coordination in the partnership constituted by the firm, the project bearer and the TRIZ expert. For this research design, the observer position was assigned to us. Nevertheless, like other academics (for instance Brown \& Eisenhardt, 1997), we wished, of course, to address the scheme with theories in mind, not to observe blindly, but also without a priori hypotheses to allow the emergence of other relevant research questions (Xxxxxxxx, 2005). In this article we will only refer to those relating to the improvement of innovation supports for SMEs.

The empirical data production has articulated three techniques (table 2). The limited number of projects followed-up (five out of twelve) and the meetings schedule (four half day sessions a few weeks apart) permit us to think that we have been able to combine a detailed knowledge of the scheme and a suitable distance from it.

Table 2. Data production techniques 
The data validation was obtained by multiangulation of data, three collection techniques and three periods of information collection (before the support instrument launch (documentation of five pilot projects), during it and afterwards (restitution activities to the actors of the scheme)). Although half the projects were observed, the empirical data study showed, retrospectively, a good level of saturation (Glaser \& Strauss, 1967).

\subsection{The guidance in the support scheme}

To highlight how new support practices may overcome the discrepancies presented in section 2, the empirical data analysis will concentrate on the coordination processes within the support scheme, on the actors' role and on the relations between firms and RTTAs.

\subsubsection{The coordination between actors}

The activities during the "official" meetings concerning the support instrument and the external exchanges are to be distinguished because the relations between the participants are different.

The actors' coordination is mainly structured around four meetings which are the location of their " mutual adjustment" (Mintzberg, 1981). The project team is made up of the project bearer, the TRIZ expert and the company, if it accepts to be present. During the meetings each person interacts with each other. The TRIZ method can be seen as a "standardisation of work processes" (Mintzberg, 1981) of the project management. This standardisation allows the actors' coordination because the job content is specified, its results are standardised and the interfaces between the tasks are predetermined.

The project bearer is the exchange animator outside the meetings. The participants are linked to this central actor without interacting with each other. This allows him to 
exchange information in a wide and loose but open network, mainly in an informal way (phone calls, e-mails). The activities coordination is based on a "standardisation of skills" (Mintzberg, 1981) : TRIZ experts and project bearers work for their clients in an autonomous way. Used alone, this mechanism is powerless. This is why the coordination, built into the support instrument both around four structured meetings and external informal contacts, form an interesting compromise.

\subsubsection{The TRIZ expert, exposed to a double bind injunction}

The TRIZ expert is the leader of the four meetings. He contributes to facilitate the participants' ideas. Several questions arise from the observation of his role.

The first one concerns his usefulness to and his influence on the SMEs. Most of the participants consider the expert as essential and that they would not have succeeded without his help. A company however didn't recognize his competence because he was just discovering their problem unlike the company technicians who had struggled with it for years and who were still looking for solutions. This reveals a double bind injunction that the TRIZ expert has to face: he has to be both an expert and an innovator. As a professional he applied structured and even standardised routines. For some people, such a behaviour is incompatible with finding innovative solutions because of the disciplinary and specialised knowledge involved. The lack of follow-up is another criticism addressed to the experts, as a company representative observed : "Some have good ideas but I think that they are not pragmatic people. (...) They don't come on the workplace to help you in the action. "7 This complaint suggests that the ways in which experts intervene might vary according to the firm's profile. In the support instrument, the TRIZ experts do more than only solving a problem defined by a company. Their role exceeds also a "doctor-patient relation" (Schein, 1987) that 
means delivering a solution to be applied by the company. In fact, they accompany it in the elaboration of solution concepts in solving problems. Their job consists however not in a "dynamic consultation" (ibid.) because the assistance in the full implementation of solutions is not a part of their missions.

Innovative solutions have mostly come from the experts' actions. So if criticism of them may be founded, expertise and innovation do not necessarily clash. The benefits of collective schemes and creativity methods such as TRIZ are precisely to overcome specialised and monodimensional points of view.

\subsubsection{The project bearer, "the third who joins"}

Two categories of actors take on the project bearer function : the technological counselors and the teachers.

The project bearer brings projects to the support instrument thanks to the regular contacts he has with the companies. At the beginning of the project, he introduces the partners who do not know each other. When companies do not participate in the scheme, he is the expert's "real client" $"$. As there is generally no specific person in SMEs to collect and to disseminate information, the project bearer is often a gatekeeper who delivers it to firms. He is also the major actor in the confidence creation process among the partners. Members may feel anxiety because of the uncertainty concerning the introduction of a new method such as TRIZ or because of the presence of unknown partners to whom confidential information will be unveiled. As the project bearer benefits from the confidence built earlier with each actor this trust is easier granted to every one he meets with. A project bearer states that " that is the salt of [his] job. "9 
The project bearer is thus the Tertius iungens, the "third who joins" (Obstfeld, 2005) of the scheme. Consisting in linking the members of his social network, his orientation is fundamental in the innovation source-based combination activity.

\subsubsection{The company, a sometimes distant beneficiary}

The SMEs involvement is often moderate in conceiving solutions during the support scheme meetings despite the fact that they are the first beneficiaries. How can we explain such involvement?

Basically, some companies have entrusted projects to another organisation because that have neither the time nor competencies to manage it by themselves. Most companies also experience difficulties in escaping routine and taking a step back: "We have no time to lose. "10 SMEs often cling to their own experience when the TRIZ expert and the project bearer try to take a step back from the problem and break with old habits. As a company representative complains : " They would have gone to the Moon but I prefer to stay on the Earth." are not used to having a look outside. (...) It is difficult to work with external partners to solve a problem. "12 SMEs are also sorry that the methods introduced are not adapted to their size or specificity as a manager reports: "I am always under the impression that we are presented tools that are not adapted to our way of working nor to our dimension (...) In SMEs constraints are not the same as in large companies. Tools should be usable in our context. "

The experts were aware that the TRIZ method introduction would not be the same in a SME as in a large company. Despite their efforts and notable advancements, the approach to adapt TRIZ to new users categories is to be ongoing. 


\subsubsection{RTTAs : the ever essential organisations to support SMEs' innovativeness}

The previous section has shown that an external expertise can both contribute to solve problems and create new ones, about confidence and confidentiality levels, when an external unknown expert enters a SME. To avoid such difficulties, an innovation introduction in a SME requires a mediation and an adaptation process based on guidance of the company (figure 4).

Figure 4. The support instrument between the SME and the innovation to be introduced.

Guidance is a relationship mode of great significance which seems to be more relevant than the expert's archetypical mode of relation in complex situations (Avenier, 2000). The mentor, contrary to the expert, associates the actors in the problem definition, helps them to develop a rich understanding and builds a solution to the identified problem with them. As these situations recover the basic roles of technological counselors in RTTAs (section 1.2), these organisations remain essential to support SME innovativeness.

The experience in the support instrument (section 2) has allowed RTTAs to overcome some usual weaknesses. For instance, its aim was to solve a real industrial problem not to introduce the TRIZ method per se (demand-oriented approach). The scrutiny of both interesting novelties and persistent difficulties encourage us to advocate new principles in order to improve SMEs' guidance in public innovation supports. 


\section{RTTAs' new principles to improve SMEs' guidance}

To reach SMEs who are behind technologically as well structurally weak and inwardlooking firms is a major goal for RTTAs (Hassink, 1996). The following strategies may be useful for progress and to improve SME guidance.

\subsection{Operate a twofold guidance}

The SMEs twofold guidance (TRIZ expert and project bearer) and the managerial innovation experienced in the support instrument, has been considered as beneficial by its actors. An expert thinks, for instance, that it is easier for the companies to understand a support scheme when they meet different actors with clearly defined but distinct roles rather than a sole person having all the competencies. The academic literature provides further arguments in favour of a double guidance (Hassink, 1996 ; Neely and al., 2000 ; Chanal, 2001). First, binomial interventions are positive because of the actors' complementarity : technical knowledge for the one and methodological support for the other. Second, the project bearer is a mediator between the expert and the company. He can avoid or limit the possible confrontation between the expert's know-how and the firm's practices. Thanks to his personal and long-lasting approach to the firm, in an informal way, he knows its trade well. So he is able to understand and to speak its managers' language. Third, learning is deeper in double guidance situations. The job done in tandem is a way to facilitate the communication between two types of expertise, to favour mutual enrichment and to accelerate the information dissemination.

\subsection{Advance gradually}

Trust relationships are a condition to exchange valuable knowledge in a support scheme especially for reaching technology-following SMEs. They can be established only 
gradually by an experienced mentor who visits firms frequently (proactive way) in order to help them to come up with some technological questions (demand-oriented approach) (Hassink, 1996). A several steps progress allows a progressive validation of the issues to be explored. If the actions of innovation centres may have modest effects, the cause is not only insufficient or inadequate support but also a lack of firms' demand. Support instruments have firstly to raise their awareness through proactive consulting, workshops or similar activities, rarely performed today (Kaufmann \& Tödling, 2002). To build confidence, step by step, support instruments should meet the more immediate and modest SME requirements and begin with incremental improvements (Vickers \& North, 2000).

\subsection{Diagnose the SME before supporting it}

Two reasons justify a careful diagnosis of a SME before supporting its innovation projects. First, if the owners' goals may be various, they are often unable to identify the firm needs (Raymond and al., 2004). Moreover, they are not aware of the strategic, organisational and technological deficiencies that hamper the innovation process (Hassink, 1996 ; Kaufmann \& Tödling, 2002). To prevent a "fire brigade" use of RTTAs when problems occur, mentors have to first raise managers' awareness if they are to offer adequate support later. This implies a diagnostic prior to the support. It generally leads to reframe the initial issue definition and to assess all its dimensions with the stakeholders : product management, markets, resources and competencies as well as strategy. Second, how can the RTTAs support innovations in a firm without knowing it well ? Contingency factors may assist or hinder the innovation introduction : explicitly or not, the firm's expectations of the product characteristics (simplicity to design or to manufacture it), the industrial standards (security regulations), the culture 
of the company (openess to outside ideas) and the members' personality (leader's presence). Mentors also have to appreciate the compatibility of the innovation to be introduced with the firm's experience (design methodologies in use, former success or failures in introducing innovations) and its appropriateness to the needs, expressed or not (Xxxxxx, 2005). Firm members are not " empty vessels" (Rogers, 1995) and they are not free of preconceptions about the promoted innovation. Knowing and understanding these representations may be decisive in the success of a support instrument.

\subsection{Differentiate guidance strategies}

It is hard to meet SMEs requirements with standard services because of the wide heterogeneity of their universe (Raymond and al., 2004). Despite this situation, most of the RTTAs act with a "take it or leave it" attitude. This can explain the problem of acceptance by the SMEs (Hassink, 1996).

As a unique guidance method is unable to meet adequately various SMEs' requirements, the ideal should be to tailor custom-made solutions. This probably asks an excessive investment from the people involved in innovations introduction. A possible compromise would be to design several guidance strategies adapted to the identified profiles of SMEs. Rather than viewing the intervention as the sale of existing knowledge or as the implementation of a planned action, it should be visualised as an ongoing transformational process (Vickers \& North, 2000). In this situation RTTAs would be both demand-oriented and supply-oriented. They would try to listen and to lead at the same time (Hassink, 1997). 


\subsection{Guide until the implementation of a solution}

In the support instrument, the SMEs guidance stopped before the solutions implementation. Three problems can be pointed out. First the "collective innovator" goes without the early learning he should get with mock-ups or prototypes. Second, the development phase is likely to never take place because innovative ideas are hard to take shape when consultants have already left. Third, cooperative learning is less marked in one-off and piecemeal interventions than during ongoing relationships. So the new practices implementation requires a continuous support until they have been “ frozen ".

\subsection{Mesh the SMEs}

Networks centred on innovations and facilitating inter-organisational learning are seen as fundamental for regional economic growth. In these networks firms interact in a generally cooperative way and public policy as well as business interests attempt to join their efforts around a long-term shared agenda. Unfortunately, SMEs are sometimes reluctant to become involved in business networks if they have no direct economic benefit. Furthermore, horizontal networking, between competitors, in industrial poles of competitivity for instance, may be difficult to achieve (Van de Ven \& Garud, 1989 ; Vickers \& North, 2000 ; Bird-Schoonhoven \& Romanelli, 2001). As RTTAs practice personal consultancy with individual firms, the RTTAs may achieve a broader impact of their services by facilitating networking between SMEs in a region through seminars and workshops (Hassink, 1996). Meetings would be devoted to developing a wide view of the innovative projects. The weak ties in "loosely-coupled networks" enhance the firms capacity to learn by themselves and to absorb new information from external 
sources. It helps managers to stand back with hindsight and to take the opinion of various actors into account.

The development of collaborative networks with SMEs should be a progressive process (Barclay \& Porter, 2005). First RTTAs would interact individually with firms in order to build a high level of trust. Second, SMEs should be encouraged to enter the network and to learn from each other. Continuations are possible by linking innovation networks at regional, national or transnational levels. Closing the partners inside their relationships is however a possible perverted effect that is to be avoided.

\section{Conclusion}

This paper has reviewed, on the one hand, the gaps of Regional Technology Transfer Agencies (RTTAs) in supporting SME innovativeness and, on the other hand, their ever essential role. Through the observation of a support scheme devoted to help SMEs to find innovative solutions to industrial problems, we have searched for original strategies to overcome traditional discrepancies between SMEs demand and RTTAs supply. Beyond the description of the progress observed, we have advocated new principles to improve the guidance of SMEs. In striving to implement them, mentors have to cope with two difficulties. First they have to allow the SME to express its creativity with a "satisfying" level of rationality but without stifling the SME with an approach that is too rigid and linear (Raymond and al., 2004). Second, they have to design support instruments with a greater "holism", for instance in the perspective of their integration within wider support systems as the innovation support policy to strengthen regional economies (North and al., 2001). When guidance principles strive to alter with a collective approach and to expand the stakeholders' vision of innovation, terms such as 
technological advisors or counselors are no longer suitable. They should probably be abandoned for new ones more appropriate for the new functions.

\section{References}

ALTSHUlleR, G. (1999) The Innovation Algorithm. TRIZ, Systematic Innovation and Technical Creativity, Worcester, MA, Technical Innovation Center.

AVENIER, M.-J. (dir.). (2000) Ingénierie des pratiques collectives, Paris : L’Harmattan.

BARCLAY, I. and PORTER, K. (2005) Facilitating innovation across SME networks, International Journal of Entrepreneurship and Innovation Management, 5 : 1/2, pp. 20-38.

BIRD-SCHOONHOVEN, C. and ROMANELLI, E. (eds) (2001) The Entrepreneurship dynamic : origins of entrepreneurship and the evolution of industries, Stanford (Cal.) : Stanford University Press.

BROWN, S.L. and EISENHARDT, K.M. (1997) The Art of Continuous Change : Linking Complexity Theory and Time-paced Evolution in Relentlessly Shifting Organizations, Administrative Science Quaterly, 42 : 1, pp. 1-34.

CHANAL, V. (2001) Vers un renouvellement des démarches d'accompagnement de l'innovation dans les PME-PMI, Entreprise et histoire, $\mathrm{n}^{\circ} 28$, pp. 37-50.

DENIS, J.L., LANGLEY, A. and ROULEAU L. (2007) Strategizing in pluralistic contexts : rethinking theoretical frames, Human Relations, $60: 1$, pp. 179-215.

GLASER, B. and STRAUSS, A. (1967) The Discovery of Grounded Theory : Strategies for Qualitative Research, London : Wiedenfield and Nicholson.

HASSINK, R. (1996) Technology transfer agencies and regional economic development, European Planning Studies, $4: 2$, pp. 167-184.

HASSINK, R. (1997) Technology transfer infrastructures : some lessons from experiences in Europe, the US and Japan, European Planning Studies, 5 : 3, pp. 167-183.

HAUSMAN, A. (2005) Innovativeness among small businesses: Theory and propositions for future research, Industrial Marketing Management, vol. 34, pp. 773-782.

KAUFMAN, A. and TÖDLING, F. (2002) How effective is innovation support for SMEs ? An analysis of the region of Upper Austria, Technovation, 22, pp. 147-159.

LUNDVALL, B.-Á. and BORRÁS, S. (1997) The Globalising Learning Economy : Implications for Innovation Policy, Luxembourg : Office for Official Publications of the European Communities.

MINTZBERG, H. (1981) The structuring of organizations : a synthesis of the research, Engelwood Cliffs : Prentice-Hall.

NEELY, A., MILLS, J., PLATTS, K., RICHARDS, H., GREGORY, M., BOURNE, M and KENNERLY, M. (2000) Performance measurement system design : developing and testing a process-based approach, International Journal of Operations and Production Management, 20 : 10, pp. 1119-1145.

NORTH, D. ; SMALlbONE, D. and VICKERS, I. (2001) Public Sector Support for Innovating SMEs, Small Business Economics, 16, pp. 303-317.

OBSTFELD, D. (2005) Social Networks, the Tertius Iungens Orientation, and Involvment in Innovation, Administrative Science Quaterly, $50: 1$, pp. 100-130.

RAYMOND, L.; BLILI, S. and EL ALAMI, D. (2004) L'écart entre le consultant et la P.M.E. : analyse et perspectives, Gestion, $28: 4$, pp. 52-60.

ROGERS, E. (1995) Diffusion of innovations, New York : The Free Press.

SCHEIN, E.H. (1987) Process Consulting : Lessons for Managers and Consultants, Reading (Ma) : AddisonWesley.

VAN DE VEN, A.H. and GARUD, R. (1989) A framework for understanding the emergence of new industries, Research on Technological Innovation Management and Policy, 4, pp. 295-225.

VICKERS, I. and NORTH, D. (2000) Regional Technology Initiatives : some Insights from the English Regions", European Planning Studies, $8: 3$, pp. 301-318.

XXXXXXXX (2005) 


\begin{tabular}{|c|c|c|c|c|c|}
\hline $\mathrm{N}^{\circ}$ & Activity & Staff & Project objective & Problem to solve & $\begin{array}{c}\text { Study } \\
\text { entrusted } \\
\text { to a TI }\end{array}$ \\
\hline 1 & $\begin{array}{c}\text { Gibletting and } \\
\text { cutting up } \\
\text { poultry }\end{array}$ & 94 & $\begin{array}{c}\text { Design and realize an automated } \\
\text { machine to cut up frozen hens' } \\
\text { legs }\end{array}$ & $\begin{array}{c}\text { Maintain the leg by the } \\
\text { drumstick without spoiling or } \\
\text { breaking the bone }\end{array}$ & yes \\
\hline 3 & $\begin{array}{c}\text { Inner } \\
\text { architecture } \\
\text { design and } \\
\text { manufacturing }\end{array}$ & 16 & $\begin{array}{c}\text { Develop a one foot table with } \\
\text { two fast shift positions (low and } \\
\text { high) }\end{array}$ & $\begin{array}{c}\text { Ensure an efficient lock in } \\
\text { each of the two positions }\end{array}$ & yes \\
\hline 4 & $\begin{array}{c}\text { Welding } \\
\text { equipment } \\
\text { design and } \\
\text { manufacturing }\end{array}$ & 110 & $\begin{array}{c}\text { Optimize the output of a motor } \\
\text { used in light aviation }\end{array}$ & $\begin{array}{c}\text { Remedy the motor output } \\
\text { decline when plane flies at } \\
\text { high speed }\end{array}$ & yes \\
\hline 5 & $\begin{array}{c}\text { Manufacturing } \\
\text { of boxes for } \\
\text { the luxury } \\
\text { industry }\end{array}$ & 106 & $\begin{array}{c}\text { Improve the productivity of the } \\
\text { assembly of cardboard boxes } \\
\text { machine }\end{array}$ & $\begin{array}{c}\text { Resinge allowing the assembly } \\
\text { automatisation } \\
\text { dilatations, play and leaks } \\
\text { existing in the present product }\end{array}$ & no \\
\hline
\end{tabular}

Table 1. Five companies and their industrial projects

\begin{tabular}{|c|c|c|}
\hline Technique & Characteristics & Justification \\
\hline $\begin{array}{c}\text { Participating } \\
\text { observation }\end{array}$ & 5 projects & $\begin{array}{l}\text { - fits well when the starting research question } \\
\text { concerns the implementation of new practices } \\
\text { where the human dimension is essential. } \\
\text { allows an understanding from the inside as well } \\
\text { as the actors' practices in the course of events. }\end{array}$ \\
\hline Interview & $\begin{array}{l}16 \text { persons, at their work place, } \\
\text { during one-to-two hour long } \\
\text { discussions. } \\
\text { All categories of actors were } \\
\text { represented. }\end{array}$ & $\begin{array}{l}\text { - relevant when it is to analyse the meaning that } \\
\text { actors give to their practices and the events to } \\
\text { which they were the active witnesses. } \\
\text { essential when we have no experience of the } \\
\text { reference world of the person questioned. }\end{array}$ \\
\hline $\begin{array}{l}\text { Case } \\
\text { study }\end{array}$ & $\begin{array}{l}\text { «traces » (documentation, } \\
\text { meetings reports...) of } 7 \\
\text { industrial cases (five from the } \\
\text { projects observed and two } \\
\text { others) }\end{array}$ & $\begin{array}{l}\text { allow the in-depth examination of complex } \\
\text { processes and the interpretation of the instrument } \\
\text { in progress according to academic literature. }\end{array}$ \\
\hline
\end{tabular}

Table 2. Data production techniques 


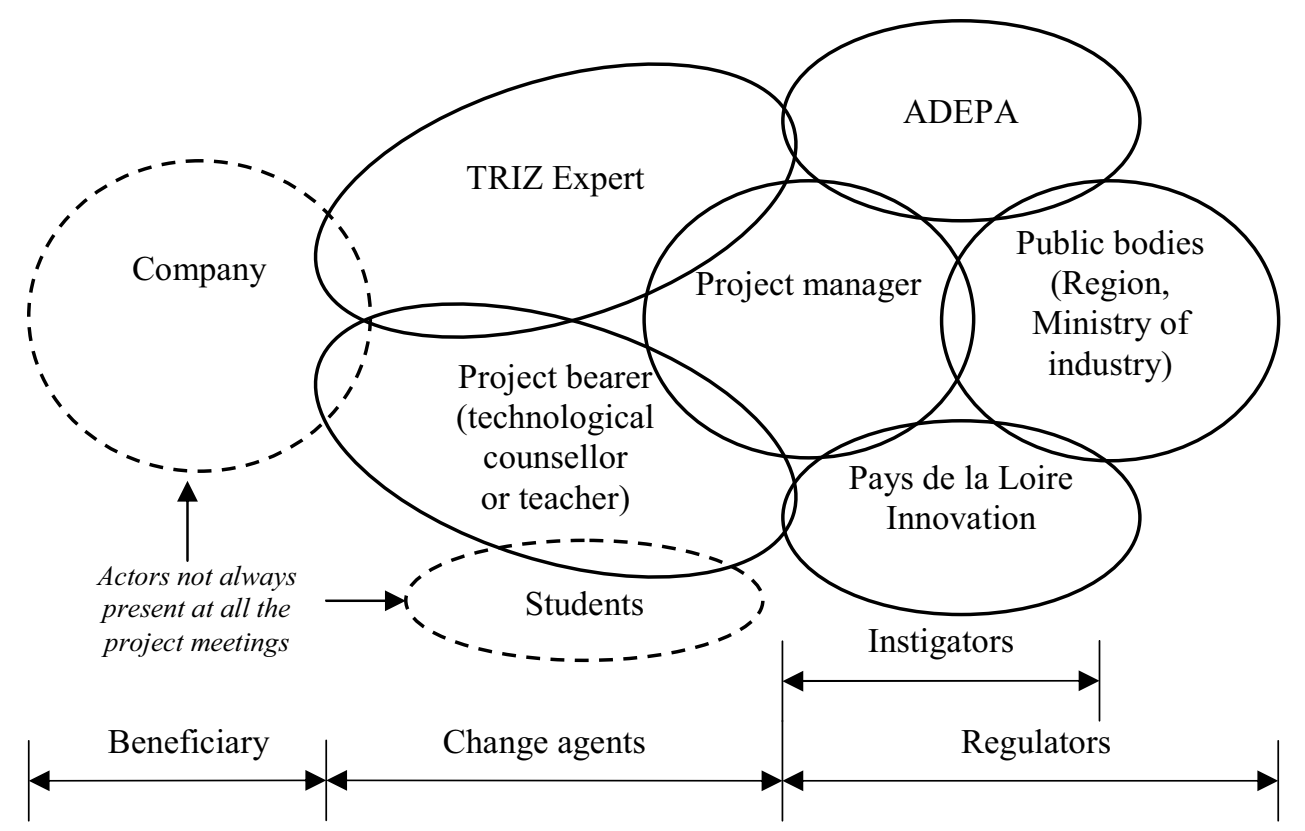

Figure 1. The actors of the support instrument.

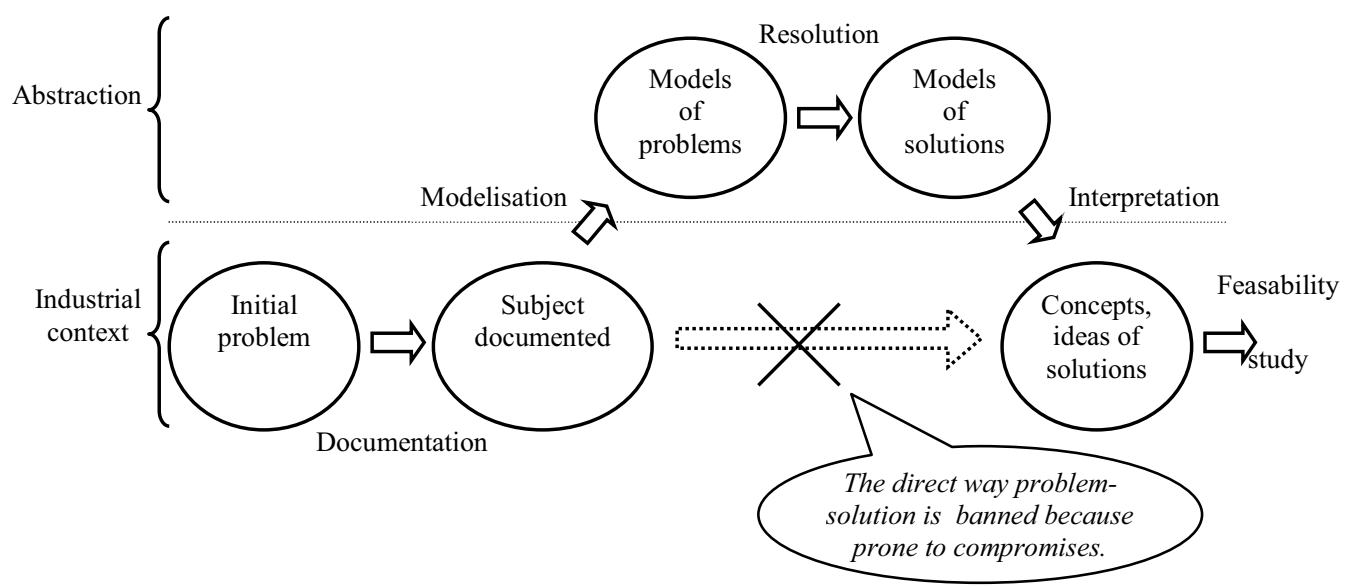

Figure 2. Approach to solve a problem with TRIZ.

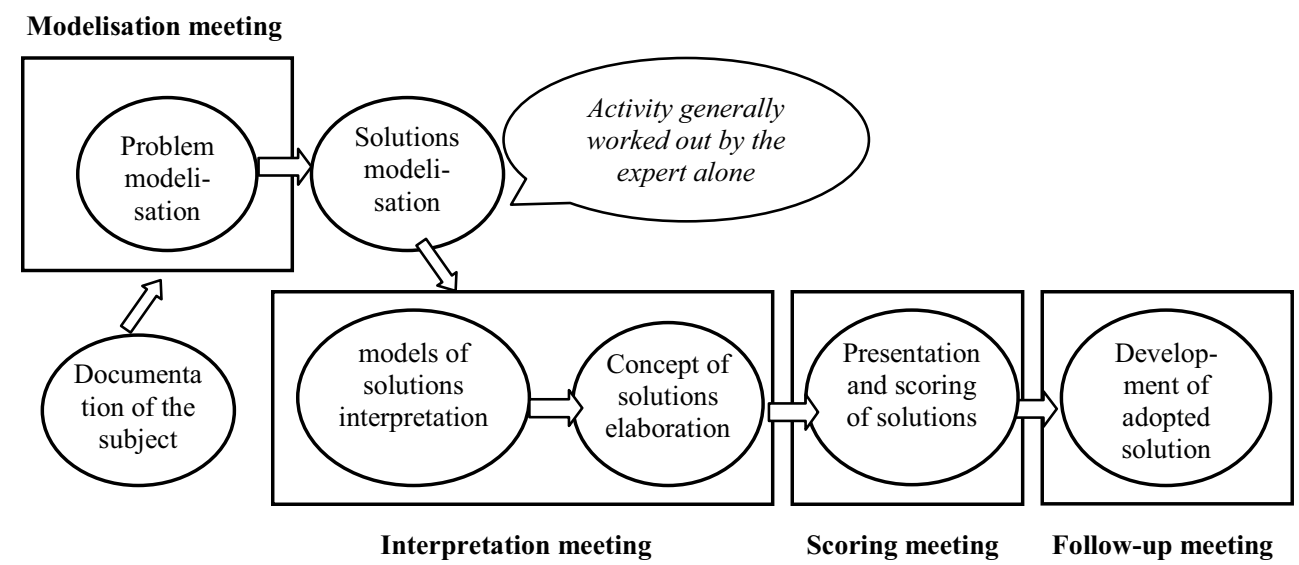


Figure 3. Typical development of a project.

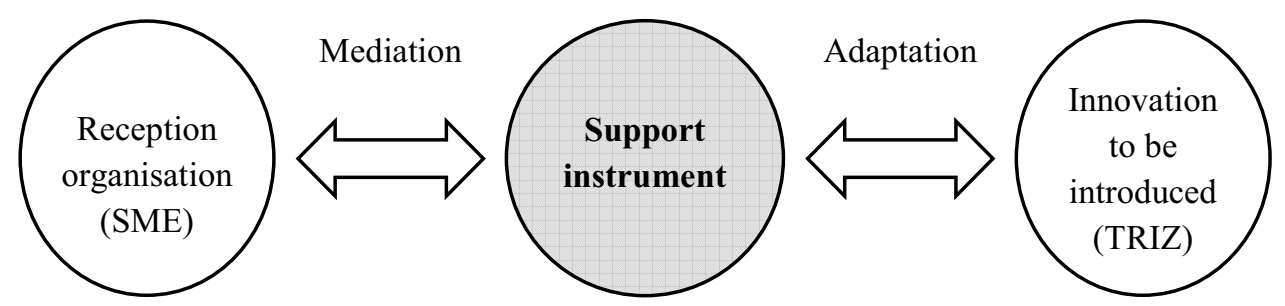

Figure 4. The support instrument between the SME and the innovation to be introduced. 


\footnotetext{
${ }^{1}$ According Denis and al. (2007), pluralistic context can be defined as organisational contexts characterised by three main features : multiple objectives, diffuse power and knowledge processes.

2 TRIZ is a method of creativity of Russian origin (Altshuller, 1999). It is used at the beginning of a design process to explore new concepts on future products or to solve recurrent problems in existing products.

${ }^{3}$ Agence pour le développement de la Production Automatisée.

${ }^{4}$ Technological Director - welding equipment company (interview 12/03/03)

${ }^{5}$ Mechanical designer - agricultural equipment company (interview 26/03/03)

${ }^{6}$ Ibid.

${ }^{7}$ Design and production manager - water supply and treatment automation company (interview 09/05/03)

${ }^{8}$ TRIZ expert (interview 03/03/08)

${ }^{9}$ RTTA Technological counselor (interview 05/05/03)

${ }^{10}$ Designer - welding equipment company (interview 28/03/03)

${ }^{11}$ Design and production manager - water supply and treatment automation company (interview 09/05/03)

${ }^{12}$ Technological Director - welding equipment company (interview 12/03/03)

${ }^{13}$ Ibid.
} 